\title{
PENGGUNAAN MEDIA TANGRAM DALAM PEMBELAJARAN MATEMATIKA PADA MATERI KESEBANGUNAN DI KELAS IX MTS SITI MARIAM BANJARMASIN
}

\author{
Sarah \& Lathifaturrahmah
}

\begin{abstract}
Abstrak
Materi kesebangunan secara teoritis dianggap sulit karena siswa kurang memahami apa perbedaan antara kesebangunan dan kekongruenan suatu bangun datar. Selain materinya memang sulit, dalam menyajikan materi guru jarang menggunakan media yang dapat menarik minat siswa dan bersifat konkrit terhadap pelajaran matematika. Oleh karena itu perlu diciptakan suatu kondisi pembelajaran yang dapat mengakrabkan matematika dengan anak, diantaranya melakukan suatu pembelajaran dengan menggunakan media tangram. Penelitian ini bertujuan untuk mendeskripsikan penggunaan media tangram dalam pembelajaran matematika pada materi kesebangunan dan untuk mengetahui faktorfaktor apa saja yang mempengaruhi penggunaan media tangram dalam pembelajaran matematika pada materi kesebangunan di kelas IX MTs Siti Mariam Banjarmasin tahun pelajaran 2014/2015.

Jenis penelitian ini adalah penelitian lapangan dengan pendekatan kualitatif dengan analisis deskriptif kualitatif. Subjek dalam penelitian ini adalah 1 orang guru yang mengajar matematika di kelas IX.B dan seluruh siswa kelas IX.B yang berjumlah 25 orang. Objek dalam penelitian ini adalah media tangram yang digunakan dalam pembelajaran matematika materi kesebangunan.

Hasil penelitian menunjukkan bahwa penggunaan media tangram pada pembelajaran matematika pada materi kesebangunan guru membagi siswa yang berjumlah 25 siswa menjadi 5 kelompok yang terdiri 5 siswa. Hasil belajar siswa pada saat berkelompok mencapai 83 dengan kategori amat baik. Faktor-faktor yang mempengaruhi media tangram dalam pembelajaran matematika pada materi kesebangunan seperti faktor siswa yaitu minat dan keaktifan siswa, faktor guru, serta faktor sarana prasarana dan fasilitas sekolah, sudah dikatakan cukup baik karena sudah memenuhi 4 faktor tersebut.
\end{abstract}

Kata Kunci: tangram, kesebangunan 


\section{Pendahuluan}

Pendidikan merupakan salah satu faktor yang penting dalam kehidupan, karena pendidikan berperan dalam mempersiapkan dan menghasilkan sumber daya manusia (SDM) yang berilmu pengetahuan tinggi serta mampu berkompetensi. Orang yang memiliki ilmu pengetahuan, kedudukan seseorang menjadi lebih tinggi derajatnya daripada orang yang tidak memiliki ilmu pengetahuan. Tugas pendidik tidak hanya memberi atau menuangkan sejumlah pengetahuan kepada siswa, tetapi mengusahakan bagaimana agar konsep-konsep penting dan sangat berguna tertanam kuat pada siswa. Siswa harus membangun pengetahuan pada dirinya sendiri. Guru dapat membantu dengan strategi mengajar ataupun media pembelajaran yang membuat pengetahuan menjadi sangat bermakna dan sangat relevan bagi siswa, dengan memberikan kesempatan kepada siswa agar menyadari dan secara sadar menggunakan strategi-strategi mereka sendiri untuk belajar.

Matematika adalah salah satu materi wajib yang diajarkan di sekolah-sekolah, dari SD, SMP/MTs, dan SMA yang sangat penting untuk dipahami. Karena, sering dimanfaatkan dalam kehidupan sehari-hari. Adanya matematika membantu manusia dalam memahami dan menguasai permasalahan sosial, ekonomi, dan alam. Seluruh segi kehidupan manusia dari yang sederhana sampai yang paling kompleks dimasuki oleh matematika. Objek matematika adalah benda pikiran yang sifatnya abstrak dan tidak dapat diamati oleh kebanyakan siswa usia Sekolah Dasar (SD) sampai SMP/MTs bahkan untuk sebagian siswa SMA sekalipun. Untuk mengatasi hal tersebut, maka dalam mempelajari suatu konsep atau prinsipprinsip matematika diperlukan pengalaman melalui benda-benda nyata (konkrit), yaitu media atau alat peraga yang dapat digunakan sebagai jembatan bagi siswa untuk berpikir abstrak.

Bagi siswa Sekolah Menengah Pertama (SMP) meskipun sudah melalui tahap “operasi konkrit”, dan berada dalam tahap awal “operasi formal", namun dalam pembelajaran matematika masih diperlukan 
Penggunaan Media Tangram dalam Pembelajaran Matematika Pada Materi Kesebangunan di Kelas IX MTs Siti Mariam Banjarmasin Tahun Pelajaran $2014 / 2015$.

penggunaan media pembelajaran secara intensif. Hal itu disebabkan karena konsep matematika yang telah diperoleh di Sekolah Dasar masih dikuasai secara samar-samar atau lemah sama sekali. Hal ini dimungkinkan karena usia Sekolah Dasar daya abstraksinya masih lemah. Dilain pihak, jika para siswa SMP/MTs memasuki pendidikan di tingkat SMA, mereka harus siap dan mampu berpikir secara formal.

Berdasarkan hal-hal tersebut di atas, maka pembelajaran matematika di SMP/MTs menjadi sangat "strategis dan rawan". Menurut Pujianti (2004 : 1) strategis dalam arti bahwa pembelajaran matematika di SMP/MTs harus merupakan pemantapan konsep, untuk kelanjutan studi matematikanya di tingkat SMA. Rawan dalam arti, jika para guru matematika di SMP kurang peduli dengan kelemahan penguasaan konsep atau teorema yang ada pada kebanyakan siswanya, maka kesalahan konsep itu akan berlanjut ke tingkat SMA yang dipastikan akan menimbulkan kesulitan dalam pembelajaran matematikanya.

Materi geometri bisa dikategorikan materi yang cukup sukar dan memerlukan pemahaman yang cukup tinggi. Hal ini sesuai dengan hasil wawancara dengan beberapa siswa dan guru matematika kelas IX MTs Siti Mariam yang menyatakan bahwa materi kesebangunan merupakan materi yang sulit untuk dipahami. Guru matematika MTs Siti Mariam, mengatakan bahwa keterbatasan fasilitas seperti media atau alat peraga merupakan salah satu kendala belajar kesebangunan. Kesulitan siswa dalam memahami materi kesebangunan ini dapat diatasi dengan menggunakan media pembelajaran yang menarik dan bersifat konkrit.

Namun, sampai saat ini masih banyak guru yang kurang perhatian terhadap media pembelajaran ketika mengajar dihadapan siswanya. Guru hanya mengandalkan metode ceramah, anggapan yang ketika topik pelajaran atau kompetensi dasar sudah disampaikan dengan lisan, siswa berarti sudah mengerti. Padahal, justru dengan lisan saja siswa akan cepat lupa sehingga tidak terdapat informasi yang melekat dalam memorinya (Yuananda, 2013 : 2). Kegiatan pembelajaran seperti itulah yang membuat 
siswa jenuh dan cepat bosan untuk belajar matematika. Kejenuhan siswa terhadap matematika menyebabkan motivasi dan minat belajar menurun sehingga dianggap sebagai materi yang sulit. Kesulitan yang dirasakan oleh siswa terhadap matematika dapat diatasi dengan menggunakan media pembelajaran yang menarik.

Menurut Rohani (1997 : 4) Media pembelajaran adalah sarana komunikasi dalam proses belajar mengajar yang berupa perangkat keras maupun perangkat lunak untuk mencapai proses dan hasil intruksional secara efektif dan efisien, serta tujuan intruksional yang lebih efektif dan memiliki sifat yang mendidik. Media pembelajaran juga memiliki kontribusi dalam meningkatkan mutu dan kualitas pembelajaran. Kehadiran media pembelajaran tidak saja membantu pengajar dalam menyampaikan materi ajarnya, tetapi memberikan nilai tambah pada kegiatan pembelajaran. Hal ini berlaku bagi segala jenis media, baik yang canggih dan mahal, ataupun media pembelajaran yang sederhana dan murah. Salah satu media pembelajaran yang dapat digunakan adalah media tangram.

Tangram merupakan salah satu permainan edukatif yang bisa dibuat dari bahan-bahan yang sederhana. Permainan ini yaitu suatu permainan puzzle persegi yang dipotong menjadi 7 bagian (2 berbentuk segitiga besar, 1 berbentuk persegi, 1 berbentuk jajaran genjang, 1 berbentuk segitiga sedang, dan 2 berbentuk segitiga kecil). Tangram banyak tersedia di pasaran namun juga mudah dibuat sendiri. Dengan memotong kertas menurut garisgaris berwarna biru, maka akan diperoleh tangram yang dimaksud dan media tangram ini sangat menyenangkan, tidak hanya menyenangkan tapi juga melatih imajinasi. Jadi, tangram dapat diartikan sebagai suatu himpunan yang terdiri dari tujuh bangun geometri datar yang dapat dipotong dari suatu persegi.

Dalam penelitian Prana D. Iswara, yang berjudul "Efektivitas Penggunaan Manual Media Tangram Media Tangram Berpetak Dalam Penguasaan Menghitung Luas Bidang Geometri Yang Diajarkan Mahasiswa Praktik Pengalaman Lapangan UPI Kampus Sumedang di Sekolah Dasar” 
Penggunaan Media Tangram dalam Pembelajaran Matematika Pada Materi Kesebangunan di Kelas IX MTs Siti Mariam Banjarmasin Tahun Pelajaran $2014 / 2015$.

pada materi geometri dalam pembelajaran matematika, penggunaan tangram dinilai baik untuk digunakan pada materi tersebut. Hal ini ditunjukkan dari rata-rata hasil belajar siswa yaitu 3,34 pada skala 4. Media tangram juga mempunyai beberapa kelebihan yaitu dapat melatih imajinasi dan kreatifitas siswa, media ini juga mudah didapat, harganya pun terjangkau, dan dapat diolah sendiri oleh para penggunanya. Permainan ini membuat ilmu geometri dapat dipahami dalam bentuk-bentuk yang sederhana dan mengasyikkan.

Dengan adanya media ini peneliti berharap bahwa pembelajaran geometri di MTs Siti Mariam dapat memotivasi siswa untuk lebih meningkatkan hasil belajar geometri khususnya pada materi kesebangunan. Untuk itu peneliti menuangkan penelitian tersebut pada judul “Penggunaan Media Tangram dalam Pembelajaran Matematika pada Materi Kesebangunan di Kelas IX MTs Siti Mariam Tahun Pelajaran 2014/2015”.

\section{Metode Penelitian}

Jenis penelitian ini adalah penelitian lapangan. Dalam penelitian ini penulis menggunakan pendekatan kualitatif. Metode yang digunakan adalah metode deskriptif. Penelitian pendekatan kualitatif dengan metode deskriptif ini bertujuan untuk memperoleh gambaran penggunaan media tangram pada materi kesebangunan kelas IX MTs Siti Mariam Banjarmasin dan faktor-faktor apa saja yang mempengaruhinya.

Subjek dalam penelitian ini adalah guru yang mengajar matematika di kelas IX dan siswa kelas IX MTs Siti Mariam Banjaramasin yang berjumlah 49 orang, peneliti mengambil sampel secara acak (Simple Random Sampling) yaitu kelas IX.B yang dijadikan sebagai subjek penelitian yang berjumlah 25 orang Siswa. Sedangkan Objek dalam penelitian ini adalah proses pembelajaran matematika dengan menggunakan media tangram pada materi kesebangunan siswa kelas IX MTs Siti Mariam Banjarmasin. 
Teknik pengumpulan data yang digunakan dalam penelitian ini adalah (1) Observasi, teknik ini digunakan untuk menghimpun data secara langsung menyangkut penggunaan media tangram pada materi kesebangunan, dan untuk memperoleh data penunjang tentang deskripsi lokasi penelitian, keadaan siswa, jumlah dewan guru dan staf tata usaha, sarana dan prasarana, serta jadwal belajar. (2) Dokumentasi, teknik ini digunakan untuk memperoleh data tentang keadaan kepala sekolah, dewan guru, siswa, media pembelajaran, sarana dan prasarana yang ada di sekolah. (3) Tes Hasil Belajar, teknik ini digunakan untuk mengetahui hasil belajar siswa dan bagaimana keterampilan siswa dalam menjawab tes tersebut setelah mengikuti proses pembelajaran dengan menggunakan media tangram. Jenis tes yang digunakan adalah soal matematika yang berbentuk uraian. (4) Angket, teknik ini merupakan usaha untuk mengumpulkan data informasi atau fakta yang menyampaikan sejumlah pertanyaan-pertanyaan secara tertulis untuk dijawab secara tertulis pula oleh responden. Selain itu teknik ini juga digunakan untuk menggali atau memperoleh data pokok, tentang faktor-faktor yang mempengaruhi penggunaan media tangram, yaitu minat dan keaktifan siswa pada saat proses pembelajaran ketika menggunakan media tangram pada materi kesebangunan. (5) Wawancara, wawancara digunakan untuk melengkapi dan memperkuat data yang diperoleh peneliti dari teknik observasi dan dokumentasi.

Teknik analisis data yang digunakan peneliti adalah (1) Analisis Data Deskripsi Penggunaan Media Tangram dalam Pembelajaran Matematika pada Materi Kesebangunan Kelas IX MTs Siti Mariam Banjarmasin Tahun Pelajaran 2014/2015. Data tentang penggunaan media tangram pada materi kesebangunan diperoleh melalui observasi, wawancara, dan tes terhadap guru dan siswa pada saat pembelajaran berlangsung yang terdiri dari kegiatan pendahuluan, kegiatan inti dan kegiatan penutup. Data tentang evaluasi yang berupa posttest pada saat berkelompok untuk mengetahui rata-rata hasil belajar siswa kelas IX.B setelah mempelajari 
Penggunaan Media Tangram dalam Pembelajaran Matematika Pada Materi Kesebangunan di Kelas IX MTs Siti Mariam Banjarmasin Tahun Pelajaran 2014/2015.

materi kesebangunan yaitu mengidentifikasi bangun-bangun datar yang sebangun dan kongruen terdiri dari 2 soal pertanyaan, tetapi untuk soal yang kedua terbagi lagi menjadi 10 pertanyaan. Teknik yang digunakan untuk menghitung hasil belajar dengan menggunakan rumus berikut: (Anas Sudijono, $2010: 40)$

$$
\mathrm{P}=\frac{f}{N} \times 100 \%
$$

Keterangan:

$P=$ Angka persentasi

$f=$ Frekuensi yang sedang dicari persentasinya

$N=$ Jumlah siswa

Rata-rata hasil belajar siswa dapat diketahui dengan diadakannya posttest pada saat siswa berkelompok dalam kegiatan pembelajaran dengan media tangram. Adapun cara yang digunakan untuk memperoleh nilai ratarata dari posttest, digunakan rumus mencari rata-rata. Untuk menentukan kualifikasi hasil belajar yang dicapai oleh siswa, dapat diketahui melalui rata-rata yang dirumuskan sebagai sebagai berikut :

$$
x=\frac{\sum f_{i} x_{i}}{\sum f_{i}}
$$

Keterangan : (Anas Sudijono, $2010: 43$ )

$x=$ nilai rata-rata (mean)

$\sum f_{i} x_{i}=$ jumlah hasil perkalian antara masing-masing data dengan frekuensinya

$\sum f_{i} \quad=$ jumlah data

Setelah dicari rata-ratanya kemudian dilakukan pengelompokkan hasil belajar siswa berdasarkan skor dengan menggunakan kualifikasi sebagai berikut: 
Tabel 1. Tabel Interpretasi Data Hasil Belajar

\begin{tabular}{|c|c|c|}
\hline No. & Nilai & Keterangan \\
\hline 1. & $95,00-100,00$ & Istimewa \\
2. & $80,00-<95,00$ & Amat Baik \\
3. & $65,00-<80,00$ & Baik \\
4. & $55,00-<65,0$ & Cukup \\
5. & $40,00-<55,00$ & Kurang \\
6. & $0,00-<40,00$ & Amat Kurang \\
\hline
\end{tabular}

(Di adaptasi dari Dinas Pendidikan Provinsi Kalimantan Selatan)

Teknik analisis data berikutnya adalah (2) Respon Siswa Terhadap Penggunaan media tangram dalam Pembelajaran Matematika pada Materi kesebangunan. Teknik yang digunakan untuk menganalisis respon siswa terhadap pembelajaran matematika materi kesebangunan menggunakan media tangram dengan menggunakan rumus sebagai berikut:

$$
p=\frac{F}{N} \times 100
$$

Keterangan:

$\mathrm{P} \quad=$ Persentasi (\%)

$\mathrm{F} \quad=$ Frekuensi jawaban responden pada masing-masing pertanyaan

$\mathrm{N}=$ Jumlah respon siswa

Untuk mengetahui baik atau tidaknya hasil dari respon siswa dapat di lihat pada tabel interpresati respon siswa dibawah ini.

Tabel 2. Interprestasi Respon Siswa

\begin{tabular}{|c|c|}
\hline Interprestasi & Kualifikasi \\
\hline $0 \%-25 \%$ & Tidak Baik \\
$25 \%-50 \%$ & Cukup Baik \\
$55 \%-75 \%$ & Baik \\
$75 \%-100 \%$ & Sangat baik \\
\hline
\end{tabular}

(Diadaptasi dari Riduan, 2010 : 89)

Setelah mengolah data dan disajikan dalam bentuk penjelasan atau uraian-uraian, maka selanjutnya adalah menganalisis data tersebut sehingga menjadi seperangkat data yang dapat menggambarkan tentang penggunaan 
Penggunaan Media Tangram dalam Pembelajaran Matematika Pada Materi Kesebangunan di Kelas IX MTs Siti Mariam Banjarmasin Tahun Pelajaran 2014/2015.

media tangram dan faktor-faktornya pada saat materi kesebangunan di kelas IX. Analisis yang peneliti gunakan adalah deskriptif kualitatif yang kemudian mengambil kesimpulan dengan induktif yaitu menarik kesimpulan yang bersifat khusus menuju kesimpulan yang bersifat umum.

\section{Hasil dan Pembahasan}

1. Deskripsi Data Penggunaan Media Tangram dalam Pembelajaran Matematika pada Materi Kesebangunan Siswa Kelas IX MTs Siti Mariam

\section{Banjarmasin}

Berdasarkan analisis peneliti, bahwa guru mata pelajaran matematika tersebut dalam pembelajaran matematika materi kesebangunan kelas IX dengan menggunakan media tangram sesuai dengan teori-teori yang penulis maksud pada bab II seperti pelaksanaan proses pembelajaran matematika di Sekolah Menengah Pertama (SMP/MTs) dan faktor-faktor yang mempengaruhi penggunaan media pembelajaran di Sekolah Menengah Pertama (SMP/MTs).

Dari sekian banyak siswa di dalam kelas, guru yang bersangkutan mampu membuat siswa aktif dan menjadikan siswa terlibat secara langsung untuk memikirkan serta menjawab pertanyaan atau soal dari materi yang telah disampaikan oleh guru yang bersangkutan menjadi bagian dari kerjasama siswa sehingga setiap siswa mampu mencontoh tiap-tiap indikator yang merupakan tujuan dari setiap kompetensi dasar yang harus dikuasai siswa.

Hasil penelitian yang peneliti lakukan berdasarkan data yang diperoleh melalui observasi dan wawancara dengan guru yang bersangkutan pada tanggal 06 September 2014, menunjukkan sebagaimana dalam penyajian data, menyatakan bahwa guru selalu menyusun rencana pelaksanaan pembelajaran (RPP) sebelum guru tersebut terjun langsung kedalam proses pembelajaran. Karena segala kegiatan dapat berhasil apabila direncanakan secara sistematis, siap dan matang. 
Hal itu juga yang dilakukan oleh guru dalam pelaksanaannya telah melalui perencanaan dan pertimbangan yang matang, sehingga dalam pertimbangan yang telah direncanakan tersebut diharapkan tercipta pembelajaran yang aktif dan menyenangkan sesuai dengan tujuan yang diharapkan setiap pertemuan pembelajaran. Dalam pelaksanaannya guru telah menyiapkan fasilitas yang menunjang kegiatan pembelajaran matematika tersebut, seperti metode dan media pembelajaran (tangram) yang digunakan.

Dari hasil penyajian data di atas dapat diketahui bahwa pelaksanaan pembelajaran dapat terlaksana dengan baik sesuai dengan langkah-langkah dalam pembelajaran.

a. Perencanaan Pembelajaran Matematika pada Materi Kesebangunan di kelas IX MTs Siti Mariam Banjarmasin dengan Menggunakan Media Tangram

Berdasarkan data yang diperoleh peneliti melalui observasi dan wawancara langsung dengan guru mata pelajaran matematika kelas IX. Guru tersebut sudah merencanakan dengan baik, dalam hal ini perencanaan seorang guru dituntut untuk mempersiapkan sebuah rencana pelaksanaan pembelajaran (RPP) yang di dalamnya menggunakan metode ekspositori, kelompok diskusi serta media tangram yang akan digunakan dalam proses pembelajaran matematika pada materi kesebangunan karena tanpa perencanaan yang matang dan kemampuan yang memadai akan kurang bisa diserap siswa.

b. Pelaksanaan Penggunaan Media Tangram dalam Pembelajaran Matematika pada Materi Kesebangunan Kelas IX MTs Siti Mariam Banjarmasin

Apabila suatu perencanaan pembelajaran telah disusun secara sistematis maka tinggal bagaimana seorang guru mampu menjalankan dan melaksanakan apa yang guru programkan dalam proses pembelajaran. Hasil penyajian data menunjukkan bahwa guru 
Penggunaan Media Tangram dalam Pembelajaran Matematika Pada Materi Kesebangunan di Kelas IX MTs Siti Mariam Banjarmasin Tahun Pelajaran $2014 / 2015$.

mata pelajaran matematika telah memilih dan menggunakan metode juga media pembelajaran (tangram) yang tepat dalam mencapai kompetensi yang diinginkan. Dengan mempertimbangkan kesesuaian metode pembelajaran dan media tangram pada materi kesebangunan yang akan dipelajari.

Dilihat dari hasil observasi yang peneliti lakukan pada tanggal 06 September 2014 pada jam 09.45 - 11.05, data-data yang terkumpul ketika proses pembelajaran di dalam kelas sedang berlangsung, dari awal pertemuan sampai akhir pertemuan yang terdiri dari kegiatan pendahuluan, inti, dan penutup. Pelaksanaan pembelajaran dimulai dengan kegiatan pendahuluan dimana guru memasuki kelas tepat waktu sebelum memulai pelajaran, guru mengucapkan salam dan seluruh siswa menjawab salam, guru menyapa siswa, guru mencek kehadiran siswa, menanyakan kepada seluruh siswa "apakah sudah siap untuk belajar", siswa pun menjawab "sudah siap bu". Guru melakukan kegiatan apersepsi seperti menanyakan kepada siswa, “apakah kalian masih ingat apa itu kesebangunan yang dulu pernah kalian pelajari waktu di kelas $V$ SD?" lalu siswa menjawab, “masih ingat”. Guru memotivasi seluruh siswa agar bersemangat dalam mengikuti pembelajaran. Pada tahap pendahuluan guru menggunakan metode ekspositori.

Memasuki tahapan yang kedua yaitu kegiatan inti, guru terlebih dahulu memberitahukan tujuan garis besar materi yang akan dipelajari “anak-anak hari ini kita akan mempelajari tentang kesebangunan yaitu mengidentifikasi bangun-bangun datar yang sebangun dan kongruen". Guru menuliskan di papan tulis apa judul materi yang akan diajarkan. Sebelum memasuki materi kesebangunan, guru kembali mengulang pertanyaan, "ayo siapa yang masih ingat lagi apa itu kesebangunan?" lalu beberapa siswa menjawab "kesebangunan adalah dua buah bangun yang memiliki bentuk yang sama walaupun ukurannya berbeda”. Lalu guru 
bertanya lagi "kalau yang dimaksud dengan kongruen itu apa?" siswa menjawab “tidak tahu bu”, guru menjelaskan dengan singkat apa itu kongruen. Kemudian guru memberikan pujian kepada siswa yang menjawab.

Guru membagi siswa yang berjumlah 25 orang menjadi 5 kelompok bersadarkan urutan no absen dari no 1 sampai no 5 itu satu kelompok, dan seterusnya. Setelah membentuk suatu kelompok guru mengatakan “hari ini kita akan belajar kesebangunan yaitu mengidentifikasi bangun-bangun datar yang sebangun dan kongruen dengan menggunakan media tangram", siswa merasa penasaran lalu bertanya" apa sih tangram itu bu?". Sebelum menjawab dan memperlihatkannya kepada siswa guru minta siswa untuk tidak ribut kemudian guru membagikan satu buah media tangram kepada setiap kelompok.

Guru menjelaskan apa itu tangram kepada siswa yang dijadikan media pada materi kesebangunan. Guru mengambil sembarang bangun datar yang ada di dalam tangram dan menyuruh siswa untuk mengambil sembarang bangun datar yang ada di dalam tangram tersebut. Guru bertanya kepada siswa “siapa yang mempunyai bangun datar persis seperti yang ibu miliki?' lalu siswa menjawab "saya bu”. Lalu guru bertanya lagi "siapa yang memiliki bangun datar seperti yang ibu miliki tapi ukurannya berbeda?' siswa menjawab lagi “saya bu”. Dari pengambilan bangun datar tersebut guru dapat menjelaskan pengertian kesebangunan dan kekongruenan.

Guru meminta setiap kelompok untuk menentukan dan membentuk beberapa bangun datar yang sebangun dan kongruen dari beberapa potongan tangram tersebut. Beberapa kelompok merasa kesulitan dalam menentukan dan membentuk sebuah bangun datar dengan menggunakan media tangram kemudian guru membantu untuk memanfaatkan media dengan sebaik-baiknya. 
Penggunaan Media Tangram dalam Pembelajaran Matematika Pada Materi Kesebangunan di Kelas IX MTs Siti Mariam Banjarmasin Tahun Pelajaran $2014 / 2015$.

Guru memberikan contoh soal, lalu guru bertanya kepada siswa “apakah sampai di sini kalian sudah paham/mengerti dan ada pertanyaan?'. Setelah semua siswa paham barulah guru memberikan latihan soal berbentuk uraian kepada setiap kelompok untuk dikerjakan dengan cara berdiskusi dan memberikan jangka waktu 25 menit untuk menyelesaikan soal. Guru juga memberikan penjelasan ketika ada kelompok yang kurang paham dengan soal latihan dan bagaimana penggunaan media tangram. Ketika waktu yang ditentukan sudah habis selesai atau tidak selesai guru menyuruh siswa untuk mengumpulkan latihan ke depan kelas. Pada tahap inti guru menggunakan metode kelompok dan diskusi.

Sebelum mengakhiri pelajaran, guru kembali menguatkan pemahaman siswa dengan bersama-sama menyimpulkan pelajaran terkait dengan materi kesebangunan yaitu mengidentifikasi bangunbangun datar yang sebangun dan kongruen. Kemudian guru mengucapkan salam dan meninggalkan siswa.

Dari hasil wawancara dengan siswa setelah pembelajaran dan observasi ketika proses pembelajaran matematika pada materi kesebangunan dengan menggunakan tangram dapat membantu siswa mempermudah mereka dalam memahami arti dari kesebangunan dan kekongruenan, menghilangkan rasa bosan, merasa aktif, meningkatkan daya pikir, menumbuhkan rasa suka terhadap geometri, melatih membedakan berbagai bentuk, mengembangkan kemampuan pemakaian kata-kata yang tepat untuk memanipulasi bentuk (misalnya memutar, membalik, menggeser), hal ini sesuai dengan beberapa kelebihan media tangram itu sendiri. Untuk lebih jelasnya, dapat dilihat pada gambar di bawah ini. 

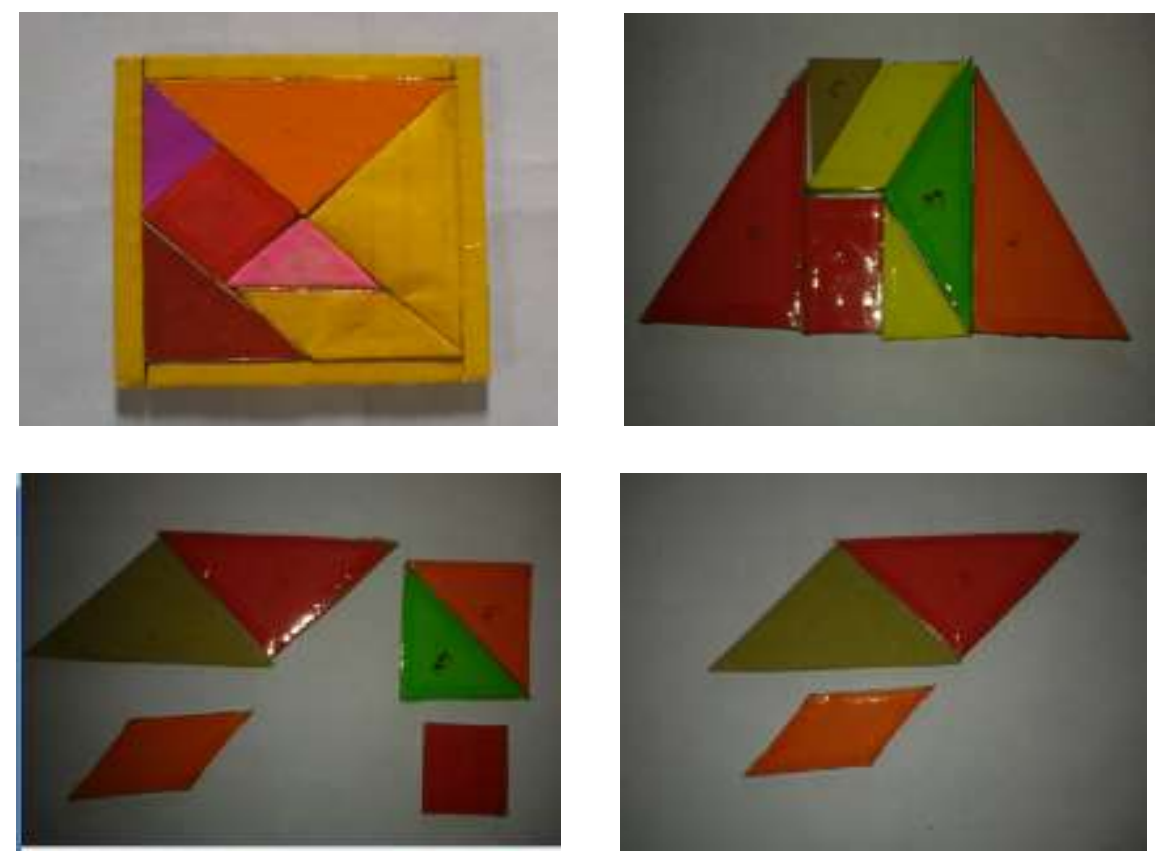

Gambar 1. Potongan Tangram yang Membentuk Bangun Datar Sebangun dan Kongruen

Gambar di atas menerangkan tangram dapat melatih siswa untuk membedakan berbagai bentuk, meningkatkan daya pikir untuk membuat berbagai macam bentuk bangun datar yang sebangun dan kongruen dari tangram tersebut.

Pada saat melakukan observasi peneliti mempunyai dokumentasi berupa beberapa foto serta keterangan tentang foto pada saat berlangsungnya proses pembelajaran.

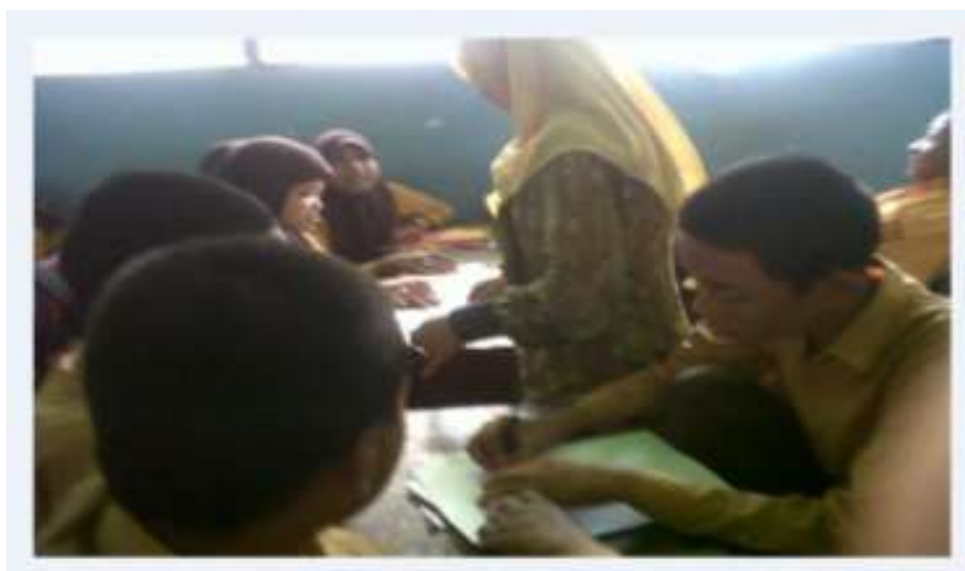

Gambar 2. Siswa Sedang Mengerjakan Soal 
Penggunaan Media Tangram dalam Pembelajaran Matematika Pada Materi Kesebangunan di Kelas IX MTs Siti Mariam Banjarmasin Tahun Pelajaran 2014/2015.

Gambar di atas ini menerangkan tentang proses pembelajaran kelompok dan siswa sedang mengerjakan soal latihan setalah menggunakan media tangram. Peran guru disini sebagai fasilitator untuk melayani setiap siswa yang bertanya karena kurang mengerti tentang penggunaan tangram dan perintah soal latihan.

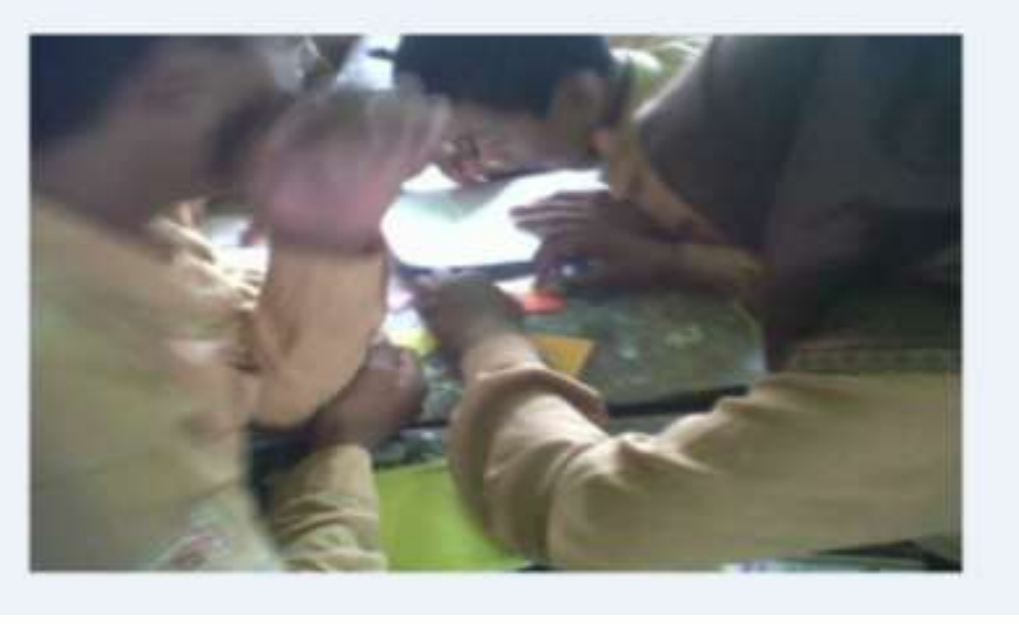

Gambar 3. Siswa Sedang Bekerjasama dalam Mengerjakan Soal

Gambar di atas ini menerangkan tentang proses pembelajaran kelompok pada saat siswa sedang menyusun beberapa potongan tangram menjadi sebuah bangun datar untuk menyelesaikan soal latihan yang diberikan, disana terlihat semua siswa aktif dan bekerjasama dengan kelompoknya.

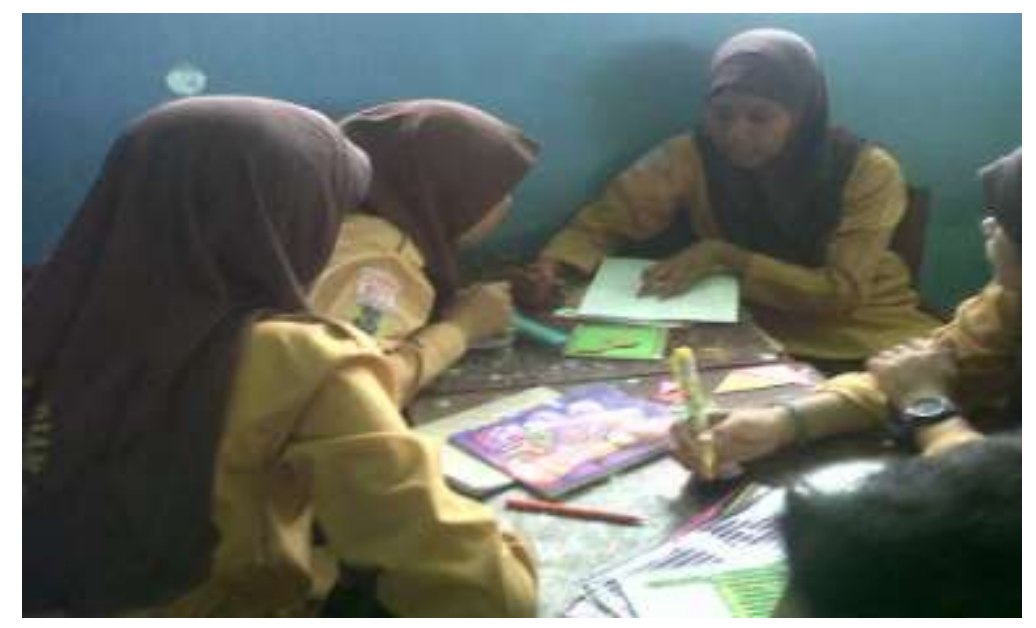

Gambar 4. Siswa Sedang Berdiskusi 
Gambar di atas ini menerangkan tentang proses pembelajaran kelompok pada saat siswa sedang berdiskusi dengan teman satu kelompoknya untuk menyelesaikan soal latihan yang diberikan dengan menggunakan media tangram.

Berdasarkan uraian di atas dan dokumentasi berupa foto-foto beserta keterangannya, bahwa guru yang mengajar mata pelajaran matematika di kelas IX MTs Siti Mariam Banjarmasin pada materi kesebangunan dengan menggunakan media tangram, sudah melaksanakan proses pembelajaran dengan baik dan benar, ini sesuai dengan langkah-langkah kegiatan yang sudah ditentukan dan disesuaikan dengan waktu yang tersedia.

Dengan demikian dapat disimpulkan bahwa guru mata pelajaran matematika kelas IX cukup mampu untuk melaksanakan proses pembelajaran matematika pada materi kesebangunan siswa kelas IX MTs Siti Mariam Banjarmasin dengan menggunakan media tangram.

\section{c. Tahap Evaluasi}

Pada tahap evaluasi diawal pembelajaran guru melakukan tanya jawab tentang materi kesebangunan yang diajarkan sebelumnya pada kelas V SD, hal ini sesuai dengan Isdisusilo pada kegiatan pendahuluan yang harus ditempuh seorang guru dalam pelaksanaan pembelajaran yaitu mengajukan pertanyaan-pertanyaan yang mengaitkan pengetahuan sebelumnya dengan pelajaran yang akan dipelajari.

Selain itu guru juga melakukan posttest pada saat berkelompok tentang penggunaan media tangram pada materi kesebangunan dengan tes tertulis. Pada jenis tes tertulis, soal yang diberikan sifatnya tidak menggunakan simbolis angka, tetapi katakata perintah yang menyuruh siswa untuk mengidentifikasi dan menganalisis antara bangun datar yang satu dengan beberapa bangun datar yang disusun dengan menggunakan media tangram 
Penggunaan Media Tangram dalam Pembelajaran Matematika Pada Materi Kesebangunan di Kelas IX MTs Siti Mariam Banjarmasin Tahun Pelajaran 2014/2015.

untuk membentuk sebuah bangun datar yang baru. Hal ini mengisyaratkan bahwa siswa diajak untuk berpikir kritis, jeli, gigih dan lebih teliti dalam mengerjakan suatu hal atau tugas. Taraf penguasaan siswa berdasarkan hasil belajar secara berkelompok dapat dilihat pada tabel berikut.

Tabel 3. Taraf Penguasaan Siswa Berdasarkan Hasil Belajar

Secara Berkelompok

\begin{tabular}{|c|c|c|c|}
\hline Nilai & Jumlah Siswa & Persentasi & Kualifikasi \\
\hline $95-100$ & 0 & 0 & Istimewa \\
\hline $80-<95$ & 20 & $80 \%$ & Amat Baik \\
\hline $65-<80$ & 5 & $20 \%$ & Baik \\
\hline $55-<65$ & 0 & 0 & Cukup \\
\hline $40-<55$ & 0 & 0 & Kurang \\
\hline $0-<40$ & 0 & 0 & Amat Kurang \\
\hline Jumlah & 25 & $100 \%$ & \\
\hline
\end{tabular}

Dari tabel di atas bahwa hasil belajar siswa secara berkelompok kelas IX B MTs Siti Mariam Banjarmasin yang memperoleh kualifikasi amat baik ada 20 orang atau $80 \%$ siswa, sedangkan kualifikasi baik ada 5 orang atau 20\% siswa. Nilai ratarata hasil belajar siswa secara berkelompok yang diambil dari tugas kelompok adalah 83 berada dalam kualifikasi hasil belajar amat baik.

\section{Faktor-faktor yang Mempengaruhi Penggunaan Media Tangram pada} Materi Kesebangunan di Kelas IX MTs Siti Mariam Banjarmasin

\section{a. Minat Siswa}

1) Semangat belajar siswa mengikuti pembelajaran matematika pada materi kesebangunan dengan menggunakan media tangram

Berdasarkan hasil angket siswa yang dapat diketahui dari responden yang memuat tentang aktifitas siswa yang bersemangat belajar dalam mengikuti pembelajaran matematika pada materi kesebangunan ketika guru menggunakan media tangram ada 15 orang ini termasuk kategori baik yaitu (60\%) ini merupakan indikator bahwa siswa berminat. 
2) Senang tidaknya siswa mengikuti pembelajaran matematika pada materi kesebangunan dengan menggunakan media tangram

Berdasarkan hasil angket siswa yang dapat diketahui dari 25 responden yang memuat tentang aktifitas siswa yang merasa sangat senang dalam dalam mengikuti pembelajaran matematika pada materi kesebangunan ketika guru menggunakan media tangram ada 16 orang ini termasuk kategori baik $64 \%$ ini merupakan indikator bahwa siswa berminat.

3) Menarik tidaknya media tangram ketika guru menggunakannya pada materi kesebangunan

Berdasarkan hasil angket siswa yang dapat diketahui dari 25 responden yang memuat tentang aktifitas siswa yang merasa sangat menarik ada 13 orang siswa yaitu (52\%) dalam mengikuti pembelajaran matematika pada materi kesebangunan ketika guru menggunakan media tangram termasuk kategori baik. Ini merupakan indikator bahwa siswa berminat.

4) Mempermudah tidaknya siswa dalam mengidentifikasi bangunbangun datar yang sebangun dan kongruen pada materi saat guru menggunakan media tangram

Berdasarkan hasil angket siswa yang dapat diketahui dari 25 responden yang memuat tentang aktifitas siswa yang merasa mudah dalam mengidentifikasi bangun-bangun datar yang sebangun dan kongruen ketika menggunakan media tangram ada 17 orang siswa yaitu (68\%) ini termasuk kategori baik, ini merupakan indikator bahwa siswa berminat.

\section{b. Keaktifan Siswa}

1) Siswa bertanya dan menanggapi saat guru menggunakan media tangram dalam pembelajaran matematika pada materi kesebangunan

Berdasarkan hasil angket siswa yang dapat diketahui menunjukkan bahwa ada 24 orang siswa yang bertanya dan 
Penggunaan Media Tangram dalam Pembelajaran Matematika Pada Materi Kesebangunan di Kelas IX MTs Siti Mariam Banjarmasin Tahun Pelajaran 2014/2015.

menanggapi saat guru menggunakan media tangram pada materi kesebangunan yaitu 96\% termasuk kategori baik. Hal ini merupakan indikator bahwa siswa aktif.

2) Siswa berdiskusi dan bekerjasama ketika berkelompok pada saat guru menggunakan media tangram dalam pembelajaran matematika pada materi kesebangunan

Berdasarkan hasil angket siswa yang dapat diketahui menunjukkan bahwa ada 22 orang siswa yang berdiskusi dan bekerjasama ketika berkelompok saat guru menggunakan media tangram pada materi kesebangunan yaitu 88 termasuk kategori baik. Hal ini ini merupakan indikator bahwa siswa aktif.

\section{c. Faktor Guru}

Sesuai dengan hasil observasi serta hasil wawancara pada hari senin tanggal 08 September 2014 dengan guru mata pelajaran matematika yaitu Ibu Mahlina, S.Pd. Berdasarkan pengalaman beliau tersebut yang sudah cukup lama mengajar serta mengikuti pelatihan khususnya pelatihan tentang media atau alat peraga maka dapat dikatakan bahwa beliau mampu menggunakan media tangram dengan langkah-langkah yang sudah direncanakan.

\section{d. Faktor Sarana Prasarana dan Fasilitas}

Berdasarkan hasil observasi dan wawancara pada hari Sabtu dan Senin, tanggal 6 dan 8 September yang peneliti lakukan bahwa keterbatasan fasilitas dalam pembelajaran matematika seperti alat peraga masih kurang. Kurangnya fasilitas yang dimiliki sekolah membuat guru jarang menggunakan media pembelajaran atau alat peraga. Tetapi untuk sarana prasarana dan fasilitas yang lain sudah cukup memadai, sehingga dapat memenuhi berbagai kebutuhan dalam menunjang proses belajar mengajar pada khususnya, dan pencapaian tujuan pembelajaran pada umumnya. 


\section{Kesimpulan}

Berdasarkan hasil penelitian maka dapat ditarik kesimpulan:

1. Pada saat penggunaan media tangram dalam pembelajaran matematika pada materi kesebangunan kelas IX MTs Siti Mariam Banjarmasin, meliputi:

a. Perencanaan penggunaan media tangram dalam pembelajaran matematika pada materi kesebangunan, yaitu ditandai dengan dibuatnya RPP sebelum melaksanakan pembelajaran.

b. Pelaksanaan penggunaan media tangram dalam pembelajaran matematika pada materi kesebangunan, yaitu dalam melaksanakannya sudah sesuai dengan langkah-langkah yang menjadi ketentuan dalam pelaksanaannya.

c. Media tangram dapat mempermudah, membantu, dan membuat siswa lebih aktif pada saat mempelajari materi kesebangunan khususnya dalam mengidentifikasi bangun-bangun datar yang sebangun dan kongruen.

d. Evaluasi yang digunakan pada saat pelaksanaan pembelajaran matematika pada materi kesebangunan dengan menggunakan media tangram. Rata-rata hasil belajar siswa pada saat berkelompok mencapai 83 dengan kategori baik sekali.

2. Berdasarkan faktor-faktor yang mempengaruhi media tangram dalam pembelajaran matematika pada materi kesebangunan adalah faktor siswa yaitu minat dan keaktifan siswa, faktor guru, serta faktor sarana prasarana dan fasilitas sekolah, sudah bisa dikatakan cukup baik.

\section{Daftar Pustaka}

Abdurahman, Mulyono, 2003. Pendidikan Bagi Anak Berkesulitan Belajar, Jakarta : Rineka Cipta.

Achmad dan Cholid Narbuka, 2007. Metode Penelitian, Jakarta : Bumi Aksara. 
Penggunaan Media Tangram dalam Pembelajaran Matematika Pada Materi Kesebangunan di Kelas IX MTs Siti Mariam Banjarmasin Tahun Pelajaran 2014/2015.

Aminah, Siti, 2012. Media Tangram Dalam Peningkatan Hasil Belajar Matematika Bangun Datar Siswa Kelas V, Surakarta, Digital Library FKIP Universitas Sebelas Maret.

Asnawir, Basirudin Usman, 2002. Media Pembelajaran, Jakarta : Ciputat Pers.

Arsyad, Azhar, 2003. Media Pembelajaran, Jakarta : PT. Raja Grafindo Persada.

Aziz Permana, http://eostudent.blogspot.com/2013/11/tangram-mediapembelajaran-matematika.html, diakses tanggal 22 Oktober 2014.

Djamarah, Saiful Bahri, dan Aswan Zain, 1996. Strategi Belajar Mengajar, Jakarta : PT Rineka Cipta.

Hasnawati, Yuni, 2008. Pembelajaran Bangun Ruang Dengan Menggunakan Alat Peraga Untuk Meningkatkan Prestasi Belajar Siswa Kelas V SD Muhammadiyah Sambisari Purwomartani Kalasan Sleman, Yogyakarta, Digital Library UIN Sunan Kalijaga.

Keputusan Kepala Dinas Provinsi Kalimantan Selatan, Pedoman Penyelenggaraan Ujian Akhir Sekolah dan Ujian Akhir Nasional Bagi Sekolah/Madrasah Tahun Pelajaran 2003/2004 Provinsi Kalimantan Selatan, Kalimantan Selatan, Pemerintah Provinsi Kalimantan Selatan Dinas Pendidikan.

Nur Basmalah, Yuananda, 2013. Pengembangan Media Pembelajaran Matematika Berbasis Multimedia Interaktif Menggunakan Software Swish Max Dengan Pendekatan Matematika Realisti Realistik Pada Pokok Bahasan Luas dan Volume Bangun Ruang Sisi Datar, Yogyakarta, Digital Library UIN sunan Kalijaga.

Nana Sudjana dan Ahmad Rivai, 1991. Media Pembelajaran, Bandung : Sinar Baru Algensindo.

Nurroh, Anisatun, 2010. Penggunaan Alat Peraga Dengan Metode Demonstrasi Untuk Meningkatkan Keaktifan dan Hasil Belajar Peserta Didik Pada Materi Luas Permukaan dan Volum Bangun Ruang di Kelas VIII B SMP Takhassus Al-qur'an Wonosobo, Semarang, Digital Library IAIN Walisongo.

Pujianti, 2004. Penggunaan Alat Peraga Dalam Pembelajaran Matematika SMP, Diklat, Yogyakarta Departemen Pendidikan Nasional Direktorat Jenderal Pendidikan Sekolah Dasar dan Menengah Pusat Pengembangan Penataran Guru (PPGG) Matematika, Yogyakarta. 
Riduwan, 2010. Belajar Mudah Penelitian untuk Karyawan dan Penelitian Pemula. Bandung : Alfabeta.

Rohani, Ahmad, 1997. Media Intruksional Edukatif. Jakarta : Rineka Cipta.

Sanjaya, Wina, 2006. Pembelajaran dalam Implementasi Kurikulum Berbasis Kompetensi. Jakarta : Kencana.

Sanjaya, Wina, 2008. Strategi Pembelajaran Berorientasi Standar Proses Pendidikan. Jakarta : Kencana Prenada Media Group.

Sardiman, 2002. Interaksi dan Motivasi Belajar Mengajar. Jakarta : Raja Grafindo Persada.

Slameto, 1995. Belajar dan Faktor-Faktor Yang Mempengaruhi. Jakarta : Rineka Cipta.

Subroto, Surya, 2007. Proses Belajar Mengajar di Sekolah, Jakarta : Rineka Cipta.

Sudijono, Anas, 2010. Pengantar Statistik Pendidikan. Jakarta : PT Raja Grafindo Persada.

Sudjana, Nana, dan Ahmad Rivai, 1997. Media Pengajaran. Bandung : PT. Sinar Baru.

Sukmadinata, 2010. Nana Syaodih, Metodologi Penelitian, Bandung, PT. Remaja Rosdakarya.

Usman, Moh. Uzer dan Lilis Setiawan, 1993. Upaya Optimalisasi Kegiatan Belajar Mengajar. Bandung : PT. Remaja Rosdakarya.

Yeni, Ety Mukhlesi, 2011. Pemanfaatan Benda-Benda Manipulatif Untuk Meningkatkan Pemahaman Konsep Geometri dan Kemampuan Tilikan Ruang Siswa Kelas V Sekolah Dasar, Aceh.

\section{Sarah}

Mahasiswa Prodi PMTK, IAIN Antasari Banjarmasin

E-mail: -

\section{Lathifaturrahmah}

Dosen Prodi PMTK, IAIN Antasari Banjarmasin

E-mail: lathifah_02@yahoo.com 